\section{Effect of seasonal conditions and milk management practices on bulk milk quality in Minas Gerais State - Brazil}

[Efeito da sazonalidade e práticas de manejo na qualidade do leite de tanque no estado de Minas Gerais - Brasil]

\author{
L.C.A. Picinin ${ }^{1,2}$, M.T. Bordignon-Luiz, ${ }^{1}$, M.M.O.P. Cerqueira ${ }^{3}$, I.M. Toaldo ${ }^{1}$, \\ F.N. Souza ${ }^{3,4^{*}}$, M.O. Leite ${ }^{3}$, L.M. Fonseca ${ }^{3}$, A.M.Q. Lana ${ }^{3}$
}

${ }^{1}$ Universidade Federal de Santa Catarina - Florianópolis, SC

${ }^{2}$ Centro de Ciências Agroveterinárias - Universidade do Estado de Santa Catarina - Lages, SC

${ }^{3}$ Universidade Federal de Minas Gerais - Belo Horizonte, MG

${ }^{4}$ Faculdade de Medicina Veterinária e Zootecnia - Universidade de São Paulo, SP

\author{
L.C.A. Picinin 1,2 \\ https://orcid.org/0000-0002-4102-7467 \\ M.T.B. Luiz1, \\ https://orcid.org/0000-0002-1217-3692 \\ M.M.O.P. Cerqueira3, \\ https://orcid.org/0000-0002-7287-2161 \\ I.M. Toaldo1, \\ https://orcid.org/0000-0001-6786-4901 \\ F.N. Souza3*, \\ https://orcid.org/0000-0002-5380-0939 \\ M.O. Leite3, \\ https://orcid.org/0000-0002-8959-2959 \\ L.M. Fonseca3, \\ https://orcid.org/0000-0001-6040-3678 \\ A.M.Q. Lana3 \\ https://orcid.org/0000-0003-0066-6198
}

\begin{abstract}
The influence of seasonality and the training and implementation of good dairy farming practices on raw milk production and quality was evaluated on dairy farms in Minas Gerais State, Brazil. The physicochemical composition, somatic cell count (SCC) and total bacterial count (TBC) were determined in 3,096 milk samples collected from bulk tanks originated from 43 dairy farms over a three-year period and correlated with key climatic factors. The recommended milking management practices were applied through a training program and correlated with the seasonal data in three stages: I) prior to training (dry period); II) 48 days after the training (transition period); III) 96 days after the training (rainy period). In the first stage, a diagnosis of the situation was performed with raw milk samplings for laboratory analysis, and training for implementation of good milking practices. In stages II and II, the checklist and laboratory analysis were also performed. The rainfall and high temperatures were found to represent the main factors affecting the milk composition and production, and TBC. The composition and physical properties of raw milk, and the TBC and SCC parameters can be controlled or minimized by applying proper milking management practices and constant monitoring.
\end{abstract}

Keywords: raw milk, weather, total bacteria count, somatic cell count, dairy farm

\title{
RESUMO
}

Avaliou-se a influência das condições climáticas em regiões tropicais, bem como do treinamento e da implementação de boas práticas de manejo na produção e qualidade do leite em distintos períodos em fazendas leiteiras no estado de Minas Gerais, Brasil. No presente estudo, as características físicoquímicas do leite, a contagem bacteriana total (CBT) e a contagem de células somáticas (CCS) foram determinadas em 3.096 amostras de tanques de leite proveniente de 43 fazendas leiteiras, durante um período de três anos, e correlacionadas com os principais fatores climáticos (temperatura diária do ar mínima, média e máxima; pluviosidade e umidade relativa). Foram avaliados os resultados obtidos nas análises das amostras de leite cru coletadas no ano anterior (2009/2010) e também no posterior (2011/2012) àquele em que foi realizado o treinamento para implementação das boas práticas de manejo de ordenha (2010/2011), compreendendo três etapas: antes do treinamento (período seco - tempo 0, etapa I), 48 dias após o treinamento (período de transição - etapa II) e 96 dias após o treinamento (período chuvoso - etapa III). Na etapa I foi realizado um diagnóstico de situação com coleta de amostras para análises laboratoriais, aplicação da lista de verificação padronizada e treinamento para a implementação das boas práticas de manejo de ordenha; na etapa II foram realizadas novas análises laboratoriais e reaplicação da lista de verificação para avaliar a eficiência do treinamento; e na etapa III foi realizada a repetição da etapa II. Com base no histórico dos três anos, observou-se que condições climáticas de alta temperatura e pluviosidade representam importantes fatores que afetam a composição do leite e o volume produzido, assim como parâmetros higiênico-sanitários do leite. Ademais, as boas

Recebido em 22 de maio de 2017

Aceito em 6 de dezembro de 2018

*Autor para correspondência (corresponding author)

E-mail: nogueirasouza@yahoo.com.br 
condições de manejo são ferramentas úteis, eficazes, práticas e essenciais para a maior produção de leite com qualidade, desde que constantemente monitoradas.

Palavras-chave: qualidade do leite cru, clima, contagem bacteriana total, contagem de células somáticas, fazenda leiteira

\section{INTRODUCTION}

Brazil hosts the second largest dairy herd in the world and is one of the largest producers and consumers of cow milk. Minas Gerais State leads the national ranking of cow milk production in Brazil, as it is responsible for approximately $27 \%$ of national milk production (Panorama..., 2015). Brazil has a tropical climate with high variability in the seasonal climatic conditions (Base..., 2012), which influences animal practices and the production and quality of foodstuffs. Most of the milk produced in Brazil is destined for national consumption and the monitoring of the quality of this essential food is of considerable relevance.

Current legislation in Brazil establishes quality parameters for raw milk, for instance, a minimum of $3.0 \%$ of total fat, $8.4 \%$ total solids and $2.9 \%$ proteins. Regarding the microbiological parameters, the permitted limits are for 500,000 cells $/ \mathrm{mL}$ for the somatic cell count (SCC) and $300,000 \mathrm{CFU} / \mathrm{mL}$ for the total bacterial count (TBC). The limits for SCC and TBC in the South, Southeast and Midwest Regions of Brazil will be formally altered in July 2018 to 400,000 cells $/ \mathrm{mL}$ and $100,000 \mathrm{CFU} / \mathrm{mL}$, respectively, in line with the standards of more demanding markets (Brasil, 2016).

The parameters defining milk quality vary according to the country, region, livestock management practices and food safety standards, and also in relation to the health aspects and hygiene conditions associated with obtaining and preserving the raw material. Well-established factors, such as low total bacterial count, low somatic cell count, high fat and protein contents, absence of residues of veterinary products and contaminants, and tuberculosis and brucellosisfree livestock, are internationally accepted indicators of milk quality and good sources of raw milk. Changes in the quality parameters of milk considerably affect the production of derivatives, as well as the safety and quality of the final product (Picinin et al., 2017).
The SCC and TBC are commonly used as microbiological parameters for the evaluation of the hygienic and sanitary quality of milk (Pantoja et al., 2009). For dairy farmers worldwide, the SCC is not only considered a measure of udder health and herd performance, but also as a determining market factor. Several physiological and environmental factors can influence the SCC in raw milk, such as the stage of lactation, age of the cow, number of lactations, season, management practices, quality and efficiency of the milking process and milking intervals. However, it has been scientifically evidenced that infection of the mammary gland is the main factor affecting the SCC (Souza et al., 2016). Also, the TBC can be considered as an indicator of sanitary conditions during milk production, which is influenced by seasonal variations affecting the dairy management practices (Elmoslemany et al., 2010).

The effects of warmer and humid climatic conditions lead to higher costs for dairy farmers, since the environmental factors of temperature and humidity can lead to heat stress in dairy cows. During warmer and rainy periods, a reduction in the production volume and total solids content of the milk are generally reported, adversely affecting the profitability of milk production (West, 2003). Also, during these periods, the herds have impaired reproductive performance and increased susceptibility to health problems, leading to the production of milk of low sanitary quality (West, 2003; Nóbrega and Langoni, 2011).

Considering the importance of raw milk quality as a precursor for the quality of drinking milk and milk products, as well as the diversity of microclimates in tropical regions, it is important to gather information on the effects of seasonal conditions and dairy management practices on important quality markers related to milk quality and food safety. In this context, this study aimed to evaluate the influence of different climatic conditions and the effect of training and the implementation of good milking management practices on the physico-chemical composition, 
total volume of milk produced and the hygienesanitary properties of bovine raw milk produced during different seasonal periods in dairy farms in Minas Gerais State, the largest milk-producing state in Brazil.

\section{MATERIALS AND METHODS}

Forty-three dairy farms in the state of Minas Gerais, Brazil, were randomly selected. Of these properties, $60 \%$ had a daily production of up to $500 \mathrm{~L}$ of milk, $10 \%$ of 501 to $1,000 \mathrm{~L}$ of milk and $30 \%$ above $1,000 \mathrm{~L}$ of milk. For each property selected, raw milk samples were collected twice monthly over a 3-year period (from 2009 to 2011), totaling 3,096 raw milk samples. Raw milk samples were collected aseptically from bulk milk tanks at the dairy farms and transported under refrigeration until subsequent analysis in the laboratory.

The physico-chemical composition (fat content, protein content, total solids and total non-fat solids) and the SCC and TBC were determined for all samples. Raw milk samples for the analysis of SCC and the physico-chemical composition were collected in $40 \mathrm{~mL}$ vials containing bronopol (2-bromo-2-nitropane-1,3diol) and analyzed on automated equipment (CombSystem 2300 ${ }^{\circledR}$, Bentley Instruments, Chaska, USA) according to IDF (Milk..., 1995) and IDF (Whole..., 2000) based on Fourier transform infrared (FTIR) for milk components and flow cytometry technology for somatic cell counting. For TBC, milk samples were collected in $40 \mathrm{~mL}$ vials containing azidiol $(3 \mu \mathrm{L} / \mathrm{mL})$ and kept at $4^{\circ} \mathrm{C}$ until the laboratory analysis. The TBC was determined by flow cytometry analysis carried out on a Bactocount $150^{\circledR}$ analyzer (Bentley Instruments, Chaska, USA). All analysis were performed in duplicate.

To investigate the influence of seasonal conditions on the quality of the raw milk produced at the selected properties, the results of the analysis of the samples collected from 2009 to 2011 were evaluated considering the different climatic conditions registered over the same period for Minas Gerais State, in the Southeast Region of Brazil. The physico-chemical composition and microbiological results determined for the raw milk samples were compiled and correlated with the climatic data (rainfall, relative humidity, and average, minimum and maximum daily temperatures) obtained from the official records of the Meteorological Center of Minas Gerais State (Base..., 2012).

The milking management practices were implemented at all of the dairy properties where raw milk samples were collected. The effect of these practices on the milk quality was then evaluated in three distinct stages (Table 1): I) before the training - dry period; II) 48 days after the training - transition period; and III) 96 days after the training - rainy period. In each stage raw milk samples were collected for laboratory analysis and the main milking practices adopted at each property were recorded. A complete training program was given to the dairy farm workers, through theoretical and practical on-site training, carried out individually at each dairy property during the sampling visits. The training program approach focused on the themes of the adoption, correctness and adaptation of practices, based on the main risk factors identified at each property as non-compliance factors for milk quality. For the monitoring of the key risk factors related to milk quality, a checklist was applied and evaluated during each visit (stages I, II, and III), according to the international recommendations on milking management practices established by FAO/IDF (Guide..., 2004) and Globalg (2010). On the checklist, each item was scored as: (C) compliant; (NC) noncompliant; or (NA) not applicable. The frequency of compliance in relation to the milking management was calculated using the formula: $[\mathrm{C} /(\mathrm{C}+\mathrm{NC}) \mathrm{x}$ 100] (Andrade and Ogliari, 2007).

All of the statistical analysis was carried out using the SAS/STAT ${ }^{\circledR}$ software (version 8, SAS ${ }^{\circledR}$ Institute Inc., Cary, NC, USA). The parametric analysis was performed by ANOVA with a randomized block design. A comparison of means test was performed using the Student's ttest for dependent samples. The correlation between quantitative variables was investigated using Pearson's correlation method ( $\mathrm{P} \leq 0.05)$. For non-parametric variables the Chi-square test was used. The differences between mean values were determined using the Wilcoxon test. The correlation between qualitative variables was investigated using the Spearman method $(\mathrm{P} \leq$ $0.05)$. The correlation was determined according to the model proposed by Finney (1980). 
Table 1. Climatic conditions in Minas Gerais State, Brazil, over the three consecutive years (2009-2011) used for classification of the seasonal periods in the study

\begin{tabular}{|c|c|c|c|c|c|c|}
\hline \multirow{2}{*}{$\begin{array}{l}\text { Reference month } \\
\text { (2009 to 2011) }\end{array}$} & \multirow{2}{*}{$\begin{array}{c}\text { Seasonal } \\
\text { period }\end{array}$} & \multirow{2}{*}{$\begin{array}{l}\text { Rainfall } \\
(\mathrm{mm})\end{array}$} & \multicolumn{3}{|c|}{ Temperature $\left({ }^{\circ} \mathrm{C}\right)$} & \multirow{2}{*}{$\begin{array}{l}\text { Relative } \\
\text { humidity } \\
(\%)\end{array}$} \\
\hline & & & Minimum & Maximum & Average & \\
\hline September & Dry & $14.49^{\mathrm{a}}$ & $16.16^{\mathrm{a}}$ & $26.56^{\mathrm{a}}$ & $20.61^{\mathrm{a}}$ & $57.98^{\mathrm{a}}$ \\
\hline November & Transition & $88.46^{\mathrm{b}}$ & $17.10^{\mathrm{b}}$ & $25.83^{\mathrm{b}}$ & $21.70^{\mathrm{b}}$ & $72.30^{\mathrm{b}}$ \\
\hline January & Rainy & $160.27^{\mathrm{c}}$ & $18.43^{\mathrm{c}}$ & $27.10^{\mathrm{c}}$ & $22.62^{\mathrm{c}}$ & $76.37^{\mathrm{c}}$ \\
\hline
\end{tabular}

SIMGE database (Base..., 2012). ${ }^{\mathrm{a}, \mathrm{b}, \mathrm{c}}$ Mean values within a column with different letters are significantly different (Student's t test, $\mathrm{P}<0.05$ ).

\section{RESULTS}

In Table 2 the correlation between the different climatic conditions and the physico-chemical properties of the raw milk, as well as the total volume produced can be observed. This table also shows the correlation between the climatic conditions and the microbiological parameters SCC and TBC determined for the raw milk samples produced at the 43 dairy farms during the study period. The correlations varied from weak to very strong according to the degree of dependence between the variables studied. Also, it appears that the quantity and quality of the milk produced is influenced by multiple factors. The monthly variations in the SCC and TBC of the raw milk samples collected over the three years period (2009 to 2011) in Minas Gerais State, Brazil, are reported in Figure 1.

The variations in the milk composition, volume of milk produced, and SCC and TBC values determined for the raw milk samples before and after the milking management training are shown in Table 3.

Table 2. Data on the correlation of variables $(\mathrm{P}<0.05)$ relating to the milk quality of 3,096 raw milk samples collected at dairy farms from 2009 to 2011 in Minas Gerais State, Brazil

\begin{tabular}{|c|c|c|c|c|c|c|c|c|c|c|}
\hline \multirow[b]{2}{*}{ Variables } & \multirow[b]{2}{*}{ Protein } & \multirow{2}{*}{$\begin{array}{l}\text { Total } \\
\text { solids }\end{array}$} & \multirow{2}{*}{$\begin{array}{c}\text { Total } \\
\text { nonfat } \\
\text { solids }\end{array}$} & \multirow[b]{2}{*}{ SCC } & \multirow[b]{2}{*}{ TBC } & \multirow[b]{2}{*}{ Rainfall } & \multicolumn{3}{|c|}{ Temperature } & \multirow{2}{*}{$\begin{array}{l}\text { Relative } \\
\text { Humidity }\end{array}$} \\
\hline & & & & & & & Min. & Max. & Average & \\
\hline $\begin{array}{c}\text { Volume } \\
\text { produced/day }\end{array}$ & & 0.76 & 0.67 & 0.36 & & & 0.33 & & & -0.45 \\
\hline Fat content & 0.76 & 0.38 & 0.51 & 0.50 & & -0.35 & $\overline{-}-\overline{61}$ & -0.63 & -0.64 & \\
\hline Protein & & 0.57 & 0.698 & $\begin{array}{c}- \\
0.37\end{array}$ & & -0.32 & $\begin{array}{c}- \\
0.43\end{array}$ & -0.41 & -0.44 & \\
\hline Total solids & & & 0.75 & & & & & & & -0.42 \\
\hline $\begin{array}{l}\text { Total nonfat } \\
\text { solids }\end{array}$ & & & & $\begin{array}{c}- \\
0.60\end{array}$ & $\begin{array}{c}- \\
0.32\end{array}$ & & $\overline{-}-\overline{53}$ & -0.45 & -0.51 & -0.34 \\
\hline SCC & & & & & 0.55 & 0.43 & 0.64 & 0.49 & 0.58 & 0.44 \\
\hline ТВC & & & & & & & 0.40 & 0.29 & 0.35 & \\
\hline Rainfall & & & & & & & 0.47 & & 0.34 & 0.72 \\
\hline $\begin{array}{l}\text { Temperature } \\
\text { (minimum) }\end{array}$ & & & & & & & & 0.89 & 0.96 & 0.43 \\
\hline $\begin{array}{l}\text { Temperature } \\
\text { (maximum) }\end{array}$ & & & & & & & & & 0.97 & \\
\hline
\end{tabular}

SCC: somatic cell count; TBC: total bacteria count; Min.: minimum; Max: maximum. 


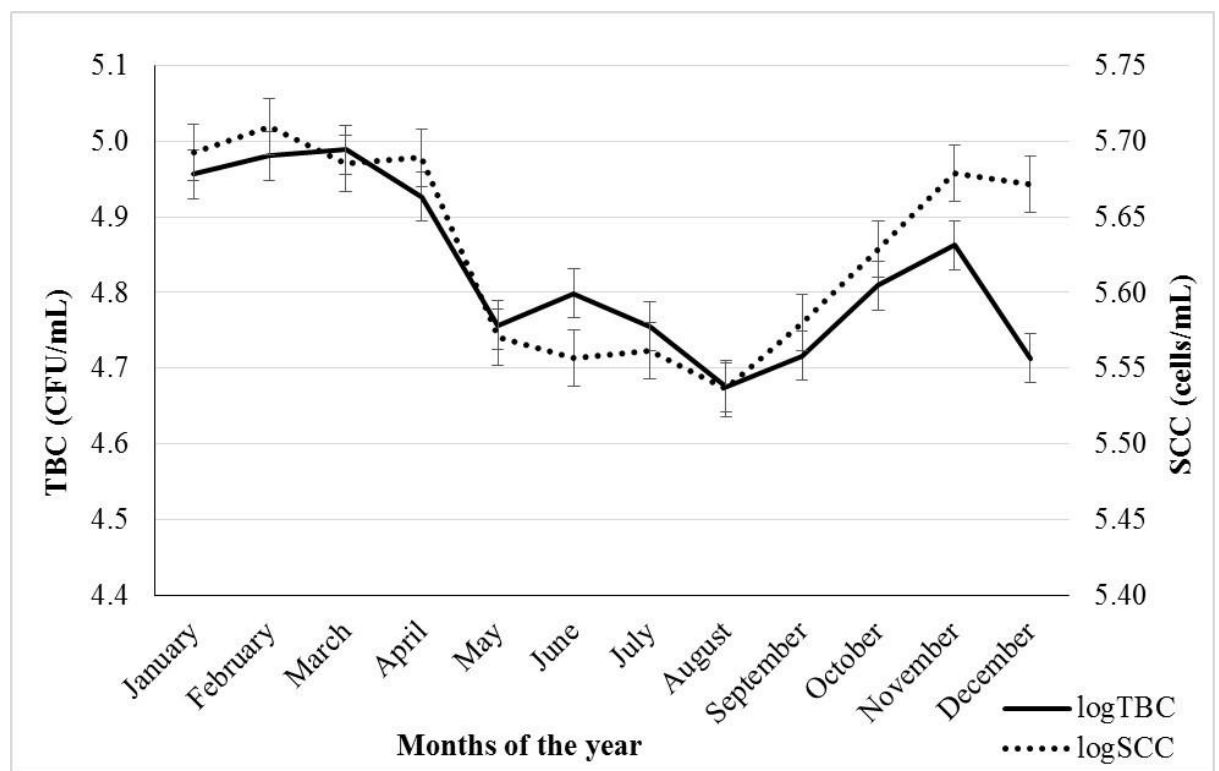

Figure 1. Monthly averages of somatic cell count (SCC) and total bacterial count (TBC) evaluated in three years (2009-2011) in refrigerated raw milk samples collected monthly in 43 dairy farms in Minas Gerais, Brazil.

Table 3. Comparison of milk composition, production volume, SCC and TBC in raw milk samples collected during the study periods before and after the training on the implementation of milking management practices

\begin{tabular}{|c|c|c|c|c|c|c|c|c|}
\hline \multirow[b]{2}{*}{ Duration } & \multirow[b]{2}{*}{$\begin{array}{c}\text { Month/year } \\
\text { (Seasonal } \\
\text { period) }\end{array}$} & \multicolumn{7}{|c|}{$\begin{array}{c}\text { Mean values and standard deviation of the physical-chemical and microbiological } \\
\text { parameters of raw milk samples }\end{array}$} \\
\hline & & $\begin{array}{l}\text { Production } \\
\text { volume } \\
\text { (L/day) }\end{array}$ & $\begin{array}{l}\text { Total } \\
\text { fat } \\
(\%)\end{array}$ & $\begin{array}{c}\text { Total } \\
\text { proteins } \\
(\%)\end{array}$ & $\begin{array}{c}\text { Total } \\
\text { solids } \\
(\%)\end{array}$ & $\begin{array}{c}\text { Total } \\
\text { nonfat } \\
\text { solids } \\
(\%)\end{array}$ & $\begin{array}{l}\log \mathrm{SCC} \\
\text { (cells } / \mathrm{mL})\end{array}$ & $\begin{array}{l}\log \mathrm{TBC} \\
(\mathrm{CFU} / \mathrm{mL})\end{array}$ \\
\hline \multicolumn{9}{|c|}{ Before implementation of the milking management practices } \\
\hline NT & Sept/2009 & $780.97^{\mathrm{a}}$ & $3.70^{\mathrm{a}}$ & $3.16^{\mathrm{a}}$ & $12.32^{\mathrm{a}}$ & $8.62^{\mathrm{a}}$ & $5.67^{\mathrm{a}}$ & $4.78^{\mathrm{a}}$ \\
\hline 12 months & Dry & (83.27) & $(0.06)$ & $(0.01)$ & $(0.07)$ & $(0.01)$ & $(0.03)$ & $(0.08)$ \\
\hline NT & Nov/2009 & $771.97^{\mathrm{a}}$ & $3.61^{\mathrm{a}}$ & $3.16^{\mathrm{a}}$ & $12.22^{\mathrm{a}}$ & $8.62^{\mathrm{a}}$ & $5.71^{\mathrm{a}}$ & $5.07^{\mathrm{b}}$ \\
\hline 10 months & Transition & $(76.92)$ & $(0.03)$ & $(0.02)$ & $(0.04)$ & $(0.02)$ & $(0.03)$ & $(0.08)$ \\
\hline NT & Jan/2010 & $551.46^{\mathrm{b}}$ & $3.63^{\mathrm{a}}$ & $3.22^{\mathrm{b}}$ & $12.20^{\mathrm{a}}$ & $8.57^{\mathrm{a}}$ & $5.71^{\mathrm{a}}$ & $5.04^{\mathrm{b}}$ \\
\hline 8 months & Rainy & $(59.60)$ & $(0.03)$ & $(0.01)$ & $(0.04)$ & $(0.02)$ & $(0.03)$ & $(0.08)$ \\
\hline \multicolumn{9}{|c|}{ Training period for implementation of the milking management practices } \\
\hline & Sept/2010 & $725.07^{\mathrm{a}}$ & $3.63^{\mathrm{a}}$ & $3.23^{\mathrm{a}}$ & $12.53^{\mathrm{a}}$ & $8.90^{\mathrm{a}}$ & $5.62^{\mathrm{a}}$ & $4.76^{\mathrm{a}}$ \\
\hline NT & Dry & $(79.70)$ & $(0.04)$ & $(0.01)$ & $(0.05)$ & $(0.02)$ & $(0.04)$ & $(0.09)$ \\
\hline $\mathrm{T}$ & Nov/2010 & $736.22^{\mathrm{a}}$ & $3.62^{\mathrm{a}}$ & $3.27^{\mathrm{b}}$ & $12.37^{\mathrm{b}}$ & $8.76^{\mathrm{b}}$ & $5.66^{\mathrm{a}}$ & $4.98^{\mathrm{a}}$ \\
\hline 48 days & Transition & (77.98) & $(0.04)$ & $(0.01)$ & $(0.04)$ & $(0.02)$ & $(0.03)$ & $(0.09)$ \\
\hline $\mathrm{T}$ & $\mathrm{Jan} / 2011$ & $769.47^{\mathrm{a}}$ & $3.68^{\mathrm{a}}$ & $3.21^{\mathrm{ab}}$ & $12.39^{\mathrm{b}}$ & $8.71^{\mathrm{b}}$ & $5.66^{\mathrm{a}}$ & $4.85^{\mathrm{a}}$ \\
\hline 96 days & Rainy & (70.71) & $(0.04)$ & $(0.01)$ & $(0.05)$ & $(0.02)$ & $(0.03)$ & $(0.08)$ \\
\hline \multicolumn{9}{|c|}{ After implementation of the milking management practices } \\
\hline $\mathrm{T}$ & Sept/2011 & $748.56^{\mathrm{a}}$ & $3.72^{\mathrm{a}}$ & $3.29^{\mathrm{a}}$ & $12.51^{\mathrm{a}}$ & $8.78^{\mathrm{a}}$ & $5.48^{\mathrm{a}}$ & $4.59^{\mathrm{a}}$ \\
\hline 12 months & Dry & (83.31) & $(0.04)$ & $(0.02)$ & $(0.05)$ & $(0.02)$ & $(0.03)$ & $(0.06)$ \\
\hline $\mathrm{T}$ & Nov/2011 & $664.37^{\mathrm{a}}$ & $3.80^{\mathrm{a}}$ & $3.27^{\mathrm{a}}$ & $12.46^{\mathrm{a}}$ & $8.65^{\mathrm{b}}$ & $5.65^{b}$ & $4.75^{\mathrm{ab}}$ \\
\hline 14 months & Transition & $(78.88)$ & $(0.04)$ & $(0.02)$ & $(0.06)$ & $(0.03)$ & $(0.03)$ & $(0.07)$ \\
\hline $\mathrm{T}$ & $\mathrm{Jan} / 2012$ & $681.01^{\mathrm{a}}$ & $3.74^{\mathrm{a}}$ & $3.22^{\mathrm{a}}$ & $12.42^{\mathrm{a}}$ & $8.69^{b}$ & $5.69^{\mathrm{b}}$ & $4.82^{b}$ \\
\hline 16 months & Rainy & (70.72) & $(0.04)$ & $(0.01)$ & $(0.04)$ & $(0.02)$ & (0.04) & $(0.07)$ \\
\hline
\end{tabular}


Table 4. Correlations between quality parameters determined for raw milk samples collected from dairy farms with frequency of compliance in relation to the milking management practices in Minas Gerais State, Brazil

\begin{tabular}{ccccccc} 
Variables & Fat & Protein & $\begin{array}{c}\text { Total } \\
\text { solids }\end{array}$ & $\begin{array}{c}\text { Total nonfat } \\
\text { solids }\end{array}$ & $\begin{array}{c}\text { Log } \\
\text { TBC* }\end{array}$ & CMM* $^{*}$ \\
\hline Milk volume /day & 0.28 & \multirow{2}{*}{0.30} & 0.29 & & & 0.42 \\
Fat & & 0.91 & 0.18 & & \\
Protein & & 0.58 & 0.78 & & \\
Total solids & & & 0.57 & 0.61 & -0.46 \\
Log SCC* & & & & & \\
Log TBC* & & & & & & \\
\hline
\end{tabular}

* Spearman test; SCC: somatic cell count: TBC: total bacteria count; CMM: frequency of compliance in relation to the milking management practices.

The correlations obtained between the quality parameters determined for the raw milk samples are shown in Table 4. From the correlation data, it was observed that the practices of milking management were positively correlated with the daily volume of produced milk $(r=0.42)$ and negatively correlated with the TBC $(r=-0.46)$. Positive and moderate $(\mathrm{r}=0.61)$ correlations were also observed between TBC and SCC.

The training, including the adaptation and correction of milking practices at the selected dairy properties, was performed during the dry period, when conditions are more favorable for the production of higher quality raw milk in relation to the rainy and transition periods. The training for the implementation of milking management practices demonstrated a significant effect $(\mathrm{P}<0.05)$, increasing the percentage of compliance regarding the parameters evaluated from 68.86 to $78.19 \%$, before and after training.

\section{DISCUSSION}

Brazil is a country with a predominantly tropical climate and it presents considerable climatic variations between regions, mainly due to its large territory. According to the SIMGE (Base..., 2012) database, a high climatic variability was observed in Minas Gerais State during the period of 2009-2011, with the average monthly rainfall ranging from zero to $240.08 \mathrm{~mm}$ (average $77.55 \mathrm{~mm}$ ). During the same period the daily average temperature in the region ranged from 6.50 to $43.0^{\circ} \mathrm{C}$ (average $20.43^{\circ} \mathrm{C}$ ). Regarding the relative humidity, the values recorded for this state over the study period ranged from 50.73 to $81.21 \%$ (average $66.62 \%$ ).
The parameters of the milk composition and quality investigated may vary according to the seasonal period in which the milk was produced. Indeed, seasonal factors influence the herd management, since during wetter and warmer periods the animals tend to be kept in pastures, in contrast to drier and cooler periods in which the animals are confined. In agreement, previous studies have shown differences in the reproductive performance, occurrence of mastitis, SCC and general health of the cow according to the grazing systems and degree of confinement applied (Goldberg et al., 1992).

The daily volume of milk produced showed positive correlations with the total solids and total nonfat solids parameters, in contrast to a negative correlation with SCC. The occurrence of infections and the presence of pathogenic microorganisms in dairy cows are generally associated with a reduction in the volume of milk produced. According to Auldist et al. (1998), this can be explained by physical damage to the secretory epithelial cells and alterations in the vascular permeability of the secretory alveolus due to an increase in the incidence of subclinical mastitis, consequently reducing the milk production. The SCC also showed a negative correlation with the percentage contents of fat, protein, and total nonfat solids. According to Le Roux et al. (2003) and $\mathrm{Li}$ et al. (2014), a decrease in the protein concentrations, especially casein, may be promoted by the action of bacterial proteases and a decreased capacity to synthesis milk can occur due to damage caused to the secretory epithelium. Also, a reduced fat content may be due to the action of lipases from the leukocyte origin (Santos et al., 2007; Li et al., 2014). 
The data in Table 1 indicate that climatic conditions exert a significant influence on most of the quality parameters of raw milk, as well as the daily volume of milk produced by dairy cows. In general, in relation to the seasonal conditions of rainfall, daily average temperature and relative humidity, a negative correlation was observed with the main physico-chemical properties of the raw milk, such as total proteins, fat content, total solids and total nonfat solids. Regarding the most important indicators for the hygiene and sanitary quality of raw milk, a positive correlation $(\mathrm{r}=0.55)$ was verified between the parameters SCC and TBC. In fact, the association between these parameters has been previously described (Pantoja et al., 2009). Furthermore, a positive correlation was also observed between the climatic conditions and these quality indicators. Among the climatic factors, the daily temperature showed the strongest positive correlation with the SCC ( $\mathrm{r}=$ $0.64)$. These findings could be associated with a decrease in the immunological defense of the animals during heat stress conditions, leading to an increased susceptibility to infections, including subclinical mastitis, and increased SCC levels in the raw milk (Das et al., 2016).

According to reports in the literature, a decrease in milk quality and the volume of production, as well as increased incidence of diseases and disorders in milking cows, mainly mastitis, can be associated with difficulties in maintaining adequate hygienic conditions during milking in warmer and wet periods (Sant'anna and Paranhos da Costa, 2011).

Furthermore, the monthly variations in the microbiological parameters SCC and TBC of the raw milk samples collected over the three year period suggest that during the warmer and wetter periods, the months of October to January present the greatest challenges in relation to the hygiene and sanitary quality of raw milk, evidenced by the greater tendency toward higher SCC and TBC values for the raw milk produced in the region of Minas Gerais State, Brazil. In agreement, according to Bueno et al. (2008) the augment in milk SCC and TBC may be due to increased accumulation of mud on dairy facilities and a higher incidence of dust on the ceilings and roofs of small dairy properties during milking. Such factors associated with failures in the milking routine may be responsible for high initial contamination and increased prevalence of mastitis in the herd. Therefore, these conditions represent important factors to be monitored in order to preserve the animal health and maintain milk quality.

Considering the influence of the seasonal conditions on important milk quality parameters, theoretical-practical training for the implementation of milking management practices was performed at the dairy farms studied. This procedure was intended to minimize or eliminate the major risk factors responsible for the decline in the quality and volume of milk produced during unfavorable weather conditions, such as rainfall and higher temperatures (October-January), as observed from the increased values for the parameters SCC and TBC during this period. The results verify that, prior to the training for the implementation of good practices in milking management, with an increase in the rainfall, daily temperature and relative humidity there was a decrease in the milk production volume and a significant increase in the milk protein content and the TBC. As previously reported by Sant'anna and Paranhos da Costa (2011), warmer and rainy environmental conditions can lead to greater difficulties in maintaining hygienic conditions at milking facilities, notably in relation to the udders of the dairy animals, affecting the SCC and TBC levels, which consequently influence the other quality parameters and the production volume. However, in relation to the time required to significantly alter the SCC results for the raw milk, the study period can be considered as short.

The training for the implementation of milking management practices demonstrated that some milk constituents such as proteins, total solids and total nonfat solids were found to be more affected by climatic conditions than by the milking practices, with reductions in their levels still occurring during unfavorable seasonal conditions. The results of this study highlight that it was possible to maintain the sanitary quality, for instance, the SCC and TBC parameters, even during hot and rainy seasons (Table 3). In this regard, Ruegg (2003) verified that the adoption and standardization of good milking practices reduces the microbial contamination of milk. 
In the rainy period, the raw milk samples showed higher values for the TBC and SCC, however, a reduction in these indicators were verified after the adoption of improved milking management practices. Our findings are consistent with those previously reported, that is, a higher incidence of mastitis associated with high rainfall levels (Nóbrega and Langoni, 2011; Sant'anna and Paranhos da Costa, 2011). Also, the results demonstrate that environmental conditions exert a strong influence on the quality of the milk produced. Prior to the training for the implementation of good milking management practices (2009/2010) and during the training period (2010/2011), the SCC levels showed no significant difference, even during the different seasonal periods. In the transition period and rainy season (2011/2012 - without training), significant increases in the SCC and TBC levels were verified (Table 3 ), evidencing that both the seasonal conditions and constant monitoring of milking practices exert a considerable influence on milk quality.

The results obtained from the analysis of the raw milk samples produced over a three-year period in Minas Gerais State, Brazil, showed that proper technical guidance and the implementation of good milking management practices are important and effective tools for improving milk quality and the quantity of milk produced, having a positive impact in the short and medium terms, especially with regard to lowering the TBC levels, even in periods which present greater hygiene and sanitary challenges, such as during the rainy season and under elevated temperature conditions. Although good practices in milking management are considered essential, the effective and continuous monitoring of milking activities is also important. Notwithstanding, there is a growing need to invest in dairy practices with better care of animals to guarantee their well-being and health, which has a direct impact on milk quality and food safety.

\section{CONCLUSIONS}

Climatic conditions were found to exert an influence on raw milk quality and the volume of milk produced at dairy farms in Minas Gerais State, Brazil. Increases in the rainfall, daily average temperature and relative humidity were negatively correlated with the volume of milk produced, as well as the milk quality in terms of its composition. These seasonal conditions were positively correlated with the parameters TBC and SCC, demonstrating that during warmer and rainy periods raw milk also tends to present lower microbiological quality. The training for the implementation of milking management practices, even in a short period, positively influenced the milk quality, mainly evidenced by the maintenance of lower TBC, and the volume of milk produced, even during the warmer and rainy periods. These seasonal periods were associated with the key challenges during milk production at dairy farms, in relation to maintaining the hygiene and sanitary quality of raw bovine milk. Additionally, the dairy industry must be continuously monitored in order to maintain the required milk quality standards and ensure animal health, productivity, profitability, and food safety.

\section{ACKNOWLEDGEMENTS}

The authors are grateful to the Brazilian Ministry of Agriculture and also the Brazilian National Council for Scientific and Technological Development $(\mathrm{CNPq})$ for financial support. The authors gratefully acknowledge Alexandre Cota Lara and the research team of the Laboratory of Milk Quality of the Federal University of Minas Gerais State, Brazil. FNS also thanks São Paulo Research Foundation - FAPESP (2014/23189-4) for his fellowship. We also thank Coordenação de Aperfeiçoamento de Pessoal de Nivel Superior - Brasil (CAPES) for the financial support.

\section{REFERENCES}

ANDRADE, D.F.; OGLIARI, P.J. Estatística para as ciências agrárias e biológicas: com noções de experimentação. Florianópolis: UFSC, 2007. 432p.

AULDIST, M.J.; WALSH, B.J.; THOMPSON, N.A. Seasonal and lactational influences on bovine milk composition in New Zealand. $J$. Dairy Res., v.65, p.401-411, 1998.

BRASIL. Ministério da Agricultura, Pecuária e Abastecimento. Instrução Normativa n.7 de 03 de maio de 2016. Regulamento Técnico de produção, identidade e qualidade do leite tipo A, do leite tipo $\mathrm{B}$, do leite tipo $\mathrm{C}$, do leite pasteurizado e do leite cru refrigerado e o 
Regulamento Técnico da coleta de leite cru refrigerado e seu transporte a granel. Diário Oficial da União, Brasília, 5 maio. 2016. Seção 1, p.11.

BUENO, V.F.F.; MESQUITA, A.J.; OLIVEIRA, A.N. et al. Total bacterial count: relationship to milk composition and period of the year in Goiás State, Brazil. Rev. Bras. Ciênc. Vet., v.15, p.4044, 2008.

DAS, R.; SAILO, L.; VERMA, N. et al. Impact of heat stress on health and performance of dairy animals: a review. Vet. World, v.9, p.260-268, 2016.

ELMOSLEMANY, A.M.; KEEFE, G.P.; DOHOO, I.R. et al. The association between bulk tank milk analysis for raw milk quality and on-farm management practices. Prev. Vet. Med., v.95, p.32-40, 2010.

FINNEY, D.J. Statistics for biologists. London: Chapman \& Hall, 1980, 168 p.

GLOBALG.A.P. Control points and compliance criteria integrated farm assurance - all farm base. 2010. Assessed at Feb 22, 2013. http://www1.globalgap.org/cms/upload/The_Stan dard/IFA/Version_4_2011/English/CPCC/10100 7_GG_IFA_CPCC_AF_ENG_Interim_Final_V4 .pdf

GOLDBERG, J.J.; WILDMAN, E.E.; PANKEY, J.W.; et al. The influence of intensively managed rotational grazing, traditional continuous grazing, and confinement housing on bulk milk tank quality and udder health. J. Dairy Sci., v.75, p.96-104, 1992.

GUIDE to good dairy farming practice. Animal production and health guidelines. Rome: FAO/IDF, 2004. 34p.

LE ROUX, Y.; LAURENT, F.; MOUSSAOUI, F. Polymorphonuclear proteolytic activity and milk composition change. Vet. Res., v.34, p.629645,2003

LI， N.; RICHOUX， R.; BOUTINAUD, M.; MARTIN, P.; GAGNAIRE, V. Role of somatic cells on dairy processes and products: a review. Dairy Sci. Technol., v.94, p.517-538, 2014.

MILK: enumeration of somatic cell. Brussels: IDF/FIL, 1995. 8p. (IDF Standard, 148A).
NÓBREGA, D.B.; LANGONI, H. Breed and season influence on milk quality parameters and in mastitis occurrence. Pesqui. Vet. Bras., v.31, p.1045-1052, 2011.

PANORAMA do leite. 2015. 14p. (Documentos, n.65). Available in: <https://www.embrapa.br/ documents/1355117/1528925/Panorama+do+Lei te+-+outubro+2015/f97da482-483f-4451-bd26e9f7e1d95c4b>. Accessed in: 21 May 2017.

PANTOJA, J.C.F.; REINEMANN, D.J.; RUEGG, P.L. Associations among milk quality indicators in raw milk bulk tank. J. Dairy Sci., v.92, p.4978-4987, 2009.

PICININ, L.C.A.; TOALDO, I.M.; HOFF, R.B. et al. Milk quality parameters associated with the occurrence of veterinary drug residues in bulk tank milk. Sci. Agric., v.74, p.195-202, 2017.

RUEGG, P.L. Practical food safety interventions for dairy production. J. Dairy Sci., v.86, p.1-9, 2003.

SANT'ANNA, A.C.; PARANHOS DA COSTA, M.J. The relationship between dairy cow hygiene and somatic cell count in milk. J. Dairy Sci., v.94, p.3835-3844, 2011.

BASE de Dados Meteorológicos e Hidrológicos. 2012. Available in: <http://www.simge.mg.gov. br/base_dados/index.html $>$. Accessed in: $18 \mathrm{Jul}$. 2012.

SANTOS, M.V.; OLIVEIRA, C.A.F.; AUGUSTO, L.F.B.; AQUINO, A.A. Atividade lipolítica do leite com células somáticas ajustadas para diferentes níveis. Arq. Bras. Med. Vet. Zootec., v.59, p.832-836, 2007.

SOUZA, F.N.; CUNHA A.F.; ROSA, D.L.S.O. et al. Somatic cell count and mastitis pathogen detection in composite and single or duplicate quarter milk samples. Pesqui. Vet. Bras., v.36, p.811-818, 2016.

WEST, J.W. Effects of heat-stress on production in dairy cattle. J. Dairy Sci., v.86, p.2131-2144, 2003.

WHOLE milk - determination of milk fat, protein \& lactose content - Guide for the operation of mid-infra-red instruments. Brussels: IDF/FIL, 2000. 12p. (IDF Standard, 141C). 